\section{Randomized Controlled Trial of Sealed In-Office Bleaching Effectiveness}

\author{
Mário Artur Pereira Santana ${ }^{1}$, Flávia Pardo Salata Nahsan² Alaíde Hermínia
} de Aguiar Oliveira', Alessandro Dourado Loguércio ${ }^{3}$, André Luis Faria-e-Silva ${ }^{1}$

\author{
'Department of Dentistry, \\ UFSE - Federal University of \\ Sergipe, Aracaju, SE, Brazil \\ ${ }^{2}$ Department of Dentistry, Campus of \\ Lagarto, UFSE - Federal University \\ of Sergipe, Lagarto, SE, Brazil \\ ${ }^{3}$ Department of Restorative \\ Dentistry, School of Dentistry, \\ UEPG - State University of Ponta \\ Grossa, Ponta Grossa, PR, Brazil
}

Correspondence: Prof. Dr. André Luis Faria e Silva, Rua Cláudio Batista s/n, Sanatório, 49060-100 Aracaju, SE. Brasil. Tel.:+55-79-2105-1824. E-mail: fariaesilva.andre@gmail.com

Key Words: adverse effects, bleaching agents, tooth bleaching, tooth discoloration.

\section{Introduction}

Despite an increased rate of successful bleaching procedures that achieve aesthetics needed for patients, the presence of sensitivity during and after treatment is still a challenge for clinicians $(1,2)$. Tooth sensitivity (TS) is related mainly to in-office bleaching protocols that use high-concentration bleaching agents, mainly hydrogen peroxide (HP) at a concentrations ranging from 25 to $38 \%$.

Although the mechanism of action of peroxides have not yet been fully established, the bleaching efficacy has been associated with the oxidative effect of free radicals, released by HP broken (4). However, it has been reported that, due to their low molecular weight, the HP molecules are capable of diffusing across the hard dental tissues to reach the pulpal chamber (6). The presence of HP and its degradation products can result in irreversible pulp cell damage and has been associated with TS after bleaching procedures (6). Nearly $70 \%$ of patients undergoing in-office bleaching report some TS during the procedure, mainly in the anterior teeth (7). The rate of patients who present TS can increase to more than $90 \%$ when the procedure involves restored anterior teeth (8). Even though TS is transitory and quickly disappears after the end of the procedure, the presence of sensitivity during the bleaching can lead to an interruption of the procedure and compromise the results. Thus, previous use of desensitizing agents (8-10), preoperative anti-inflammatory drugs (11-12) and anti-oxidative agents (13) has attempted to reduce the TS associated with in-office bleaching procedures. The success of this pretreatment remains controversial. Another concern is that this procedure adds an extra step to the bleaching protocol, which is against the current preference for simplification and shortening of chairside time, mainly because one of the alleged advantages of in-office bleaching is the fast whitening results.

An interesting alternative has recently been tested in an in vitro study (14), in which covering the bleaching agent during the in-office bleaching procedure reduced the amount of HP that reached the pulp chamber, without changing the bleaching outcome. This technique, called sealed in-office bleaching, involves the application of a high-concentration bleaching agent onto the buccal enamel surface, followed by the placement of a linear low-density polyethylene tray, similar to those used during at-home bleaching, which prevents dehydration of the gel and could explain the lower peroxide penetration into the pulp chamber. To the best of our knowledge, no clinical study has been performed testing this technique. Thus, the aim of this preliminary study was to evaluate the effectiveness of the sealed protocol for the in-office bleaching, with respect to $\mathrm{TS}$ and $\mathrm{BE}$, compared with conventional bleaching technique. The tested hypothesis is that the sealed protocol reduces the TS during the inoffice bleaching without altering the BE. 


\section{Material and Methods}

This clinical investigation was approved by the local Scientific Review Committee and Committee for the Protection of Human Subjects (Protocol \# 18538713.2.0000.5546). The study description follows the CONSORT statement (15). Prior to the bleaching procedures, all volunteers underwent dental screening and professional pumice prophylaxis and signed an informed consent form.

\section{Study Design.}

This was a randomized, single-blinded, controlled trial with a parallel group and an equal allocation rate to receive either one of two treatments. The study was conducted at the Dental Clinic of the School of Dentistry of the Federal University of Sergipe (UFS) from May 2013 to November 2013.

\section{Inclusion and Exclusion Criteria}

Patients in this clinical trial were at least 18 years old and had good general and oral health. Participants were recruited from the patients attending the Dental Clinic. The participants were required to have the six cariesfree maxillary anterior teeth without restorations and/or endodontic treatment. Participants were excluded from the study if they had undergone tooth bleaching procedures or were pregnant/lactating; had severe internal tooth discoloration (tetracycline stains, fluorosis, pulpless teeth); were taking any kind of medicine, had bruxism habits or any other pathology that could cause sensitivity (such as recession or dentin exposure); and were smokers with periodontal diseases. Those individuals would not be eligible for an immediate cosmetic treatment, such as bleaching. Participants who reported continuous use of drugs with antiinflammatory actions were also excluded from the study.

\section{Sample Size Calculation}

The primary outcome of this study was the absolute risk of TS. The sample size was calculated using the absolute risk of TS (100\%) found in a previous study using a single 45-min application of the same bleaching agent of this study (Whiteness HP Maxx, FGM, Joinville, SC, Brazil) (16). Thus, 20 patients were required to have $80 \%$ chance of detecting, as significant at the $5 \%$ level, a decrease in primary outcome measure from $100 \%$ in the control group to $50 \%$ in the experimental group.

\section{Study Intervention}

Twenty participants were randomly subjected to a conventional in-office bleaching protocol (control) or to an experimental protocol of sealed in-office bleaching. Two participants received one bleaching per day; the protocol used for the first participant was randomly defined at the moment of initiating the bleaching, and the second participant was allocated to other protocol.

\section{Baseline Measurements}

Prior to the bleaching procedures, the tooth sensitivity and shades of the six maxillary anterior teeth were evaluated. The teeth sensitivity was evaluated by using a Visual Analogue Scale (VAS), which consisted of a $10-\mathrm{cm}$ color scale from green (no sensitivity) to red (unbearable sensitivity). A slightly air-stream was applied over the buccal surfaces of the central incisors, and the patients recorded their sensitivity perception by pointing with a pen on the scale. The distance between the marking and the border of scale, relative to the absence of sensitivity was measured. The measurements were scored according to: 0 - until 1.6 $\mathrm{cm} ; 1$ - between 1.7 and $3.3 \mathrm{~cm} ; 2$ - between 3.4 and 5 $\mathrm{cm} ; 3$ - between 5.1 and $6.6 \mathrm{~cm} ; 4$ - between 6.7 and 8.3 $\mathrm{cm}$; and 5 - between 8.4 and $10 \mathrm{~cm}$. A spectrophotometer (Easy Shade Compact, Vita-Zahnfabrik, Bad Säckinge, Germany) was used to measure the tooth shade. The values of $L^{*}$ (brightness), $a^{*}$ (hue in red-green axis) and $b^{*}$ (hue in blue-yellow axis) were recorded. Three measurements were performed for each tooth, while the means of $L^{*}$, $a^{*}$ and $b^{*}$ values were used in the analysis of the shades. A dense silicon index, extending from canine to canine, was confectioned to create a standard of the evaluation during the study. The index presented a perforation with approximately $6 \mathrm{~mm}$ of the diameter to permit the placement of the spectrophotometer tip.

\section{Intervention}

Two clinicians performed the bleaching procedures. Previously, the gingival tissue of the teeth to be bleached was protected with a light-activated resin dam (Top Dam, FGM, Joinville, SC, Brazil). The 35\% HP gel (Whiteness HP Maxx) was used in a single 45-min application for both groups, in accordance to the previous study (16). For the sealed bleaching protocol, a customized bleaching tray (similar to the one used for at-home bleaching) was fabricated with acetate and carefully positioned over the bleaching agent. The sequence of tray placement for the sealed protocol is illustrated in Figure 1. For both protocols, only one session of bleaching was performed.

\section{TS Evaluation}

The patients recorded their perceptions of TS at 20 and 40 min during the bleaching procedures using VAS. TS was also evaluated immediately after the bleaching procedures using the same scale. Data were arranged into two categories: percentage of patients who reported TS at least once during the bleaching procedure (absolute risk of TS) and overall TS intensity. The first measure represented 
the likelihood that sensitivity would occur, and the second was the level of intensity likely to be incurred.

\section{Shade Evaluation}

The shades of the six maxillary anterior teeth were recorded 7 and 28 days after the bleaching process. In these times, the $\Delta \mathrm{E}$ was calculated by the following equation: $\Delta \mathrm{E}=\left[(\Delta \mathrm{L})^{2}+(\Delta \mathrm{a})^{2}+(\Delta \mathrm{b})^{2}\right]^{1 / 2}$, while $\Delta \mathrm{L}=\mathrm{L} 1-\mathrm{L} 0 ; \Delta \mathrm{a}=$ a1 - a 0 ; e $\Delta b=b 1-b$.

\section{Statistical Analysis}

The analysis followed the intention-to-treat protocol and involved all participants who were randomly assigned (20). The statistician was blinded to the study groups. The primary outcome absolute risk of TS was compared by using the Fisher Exact test. The confidence interval for the effect size was calculated.

TS intensity (secondary outcome) was compared by using the Mann-Whitney $\mathrm{U}$ test (between two groups at the three different evaluation times) and using the Friedman tests (between times within each group). Color change, another secondary endpoint, was used to assess the efficacy of the bleaching treatment. $\Delta \mathrm{E}$ data of both groups were analyzed by repeated-measures ANOVA. In all statistical tests, a pre-set alpha of $5 \%$ was used.

\section{Results}

The mean age (years) of the participants in this study was similar between the groups (conventional technique $=22.8 \pm 2.7$ and sealed technique $=21.0 \pm 2.0$ years; $p=0.23$ ). Forty percent of the participants from the groups were male.

\section{Tooth Sensitivity}

Regarding the absolute risk of TS, no significant difference was observed between the groups (Table $1 ; p=0.15$ ). The relative risk, as well as the $95 \%$ confidence interval, is also evidence that the use of the sealed technique had no effect on the TS reduction. Regarding the TS intensity, the groups differ statistically only at 40 min of bleaching (Table $2, p=0.03$ ), with a higher intensity of TS for the conventional technique. At 20 min of procedure and immediately after bleaching agent removal, both techniques did not differ statistically (Table 2, $p=0.07$ and $p=0.82$, respectively).

\section{Color Evaluation}

Repeated-measures ANOVA did not show a significant
Table 1. Comparison of number of patients who experienced tooth sensitivity during bleaching regimen in both groups, including absolute and relative risks

\begin{tabular}{|c|c|c|c|c|c|}
\hline \multirow{2}{*}{$\begin{array}{l}\text { Bleaching } \\
\text { technique }\end{array}$} & \multicolumn{2}{|c|}{$\begin{array}{l}\text { Tooth sensitivity } \\
\text { during treatment }\end{array}$} & \multirow{2}{*}{$\begin{array}{c}\mathrm{p} \\
\text { value * }\end{array}$} & \multirow{2}{*}{$\begin{array}{c}\text { Absolute risk } \\
\left(95 \% \mathrm{Cl}^{* * *}\right)\end{array}$} & \multirow{2}{*}{$\begin{array}{r}\text { Relative risk } \\
\left(95 \% \mathrm{Cl}^{* *}\right)\end{array}$} \\
\hline & Yes & No & & & \\
\hline Conventional & 9 & 1 & \multirow{2}{*}{0.15} & $90(59-98)$ & \multirow{2}{*}{$0.44(0.20-0.97)$} \\
\hline Sealed & 4 & 6 & & $40(16-68)$ & \\
\hline
\end{tabular}

${ }^{*}$ Fisher's exact test $(\alpha=5 \%)$. ${ }^{* *}$ Confidence interval.

Table 2. Medians (minimum/maximum values) of scores of tooth sensitivity intensity (0-5) experienced by patients for each treatment group at different evaluation times

\begin{tabular}{llcc}
\hline \multirow{2}{*}{$\begin{array}{l}\text { Evaluation } \\
\text { time }\end{array}$} & \multicolumn{2}{c}{ Bleaching technique } & $\mathrm{p}$ \\
\cline { 2 - 3 } value $^{*}$ & Conventional & Sealed & \\
\hline$\leq 20 \mathrm{~min}$ & $1(0 / 2) \mathrm{Aa}, \mathrm{b}$ & $0(0 / 1) \mathrm{Ab}$ & 0.07 \\
20 to $40 \mathrm{~min}$ & $1.5(0 / 3) \mathrm{Aa}$ & $0(0 / 1) \mathrm{Bb}$ & 0.03 \\
lmmediately after & $0(0 / 1) \mathrm{Bb}$ & $0(0 / 1) \mathrm{Bb}$ & 0.82 \\
\hline
\end{tabular}

*At each period, the two treatments were compared with the Mann-Whitney $U$ test and significant differences are represented by different uppercase letters. For each treatment, the three periods were compared with Friedman test and differences are represented by different lowercase letters $(\alpha=0.05)$.
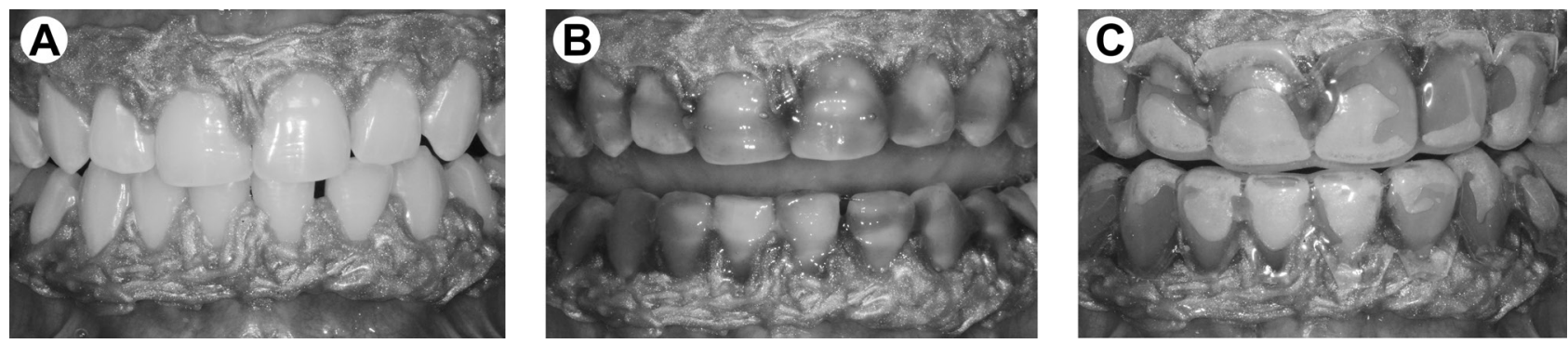

Figure 1. Clinical sequence for sealed bleaching technique. A: Isolation with light-activated resin dam. B: Application of $35 \%$ hydrogen peroxide gel. Placement of customized bleaching tray in the maxillary and mandibular arches (C). 
effect for the factors 'bleaching technique' $(p=0.69)$ and 'evaluation time' ( $p=0.14)$. The interaction between the factors was not statistically significant either $(p=0.78)$. The results are displayed in Table 3.

\section{Discussion}

The results of the present study indicated that the absolute risk of TS observed during the bleaching procedure was $90 \%$ when the conventional protocol used. This is similar to outcomes from other studies that evaluated sensitivity of in-office bleaching with $35 \% H_{P}(12,13,16)$. On the other hand, covering the bleaching agent during the procedure reduced the risk of TS to $40 \%$. However, although the number of patients who experienced tooth sensitivity during bleaching regimen in both groups was statistically similar, the level of sensitivity during the bleaching procedure was reduced with the use of the sealed technique, showing statistical difference from conventional one at $40 \mathrm{~min}$ of bleaching.

Despite several hypotheses that attempt to explain the association between TS and bleaching agents, the most accepted theory is a higher penetration of HP and its degradation products that penetrate through the tooth hard tissues to reach the pulp chamber (17). The presence of HP and its degradation products may cause cell death and reduced cell proliferation (18). This damage occurs mainly to the odontoblast layer of underlying dentin. A previous in vitro study evaluated the effect of covering the bleaching agent (sealed technique) on the color change and level of penetration of HP into the pulp chamber (14). The results showed a lower penetration of HP into the pulp chamber for the sealed technique compared to the conventional technique. Furthermore, no difference in the color change was observed between the two techniques (14).

Based on the fact that the differences among TS were more evident after $20 \mathrm{~min}$, we speculate that this is directly related to the difference of the concentration of HP and its products in the pulp chamber between the techniques. Of course, it can be expected for an increasing of HP concentration in the pulp chamber with the longer times of exposition (19). Thus, despite the fact that better results are observed with a sealed protocol, this technique did not solve the TS, if used for a longer period of time.

Table 3. Means $\left(95 \% \mathrm{Cl}^{*}\right)$ of $\Delta \mathrm{E}$

\begin{tabular}{lcc}
\hline $\begin{array}{c}\text { Evaluation } \\
\text { period }\end{array}$ & $\begin{array}{c}\text { Conventional } \\
\text { technique }\end{array}$ & $\begin{array}{c}\text { Sealed } \\
\text { technique }\end{array}$ \\
\hline 7 days & $7.4(6.2-8.6)$ & $7.8(6.8-8.8)$ \\
28 days & $8.1(7.0-9.2)$ & $8.3(6.2-10.4)$ \\
\hline
\end{tabular}

*Confidence interval
Actually, the use of a single 45-min application for agent bleaching was used for both techniques in the present study, in contrast to the manufacturer's recommendation of three 15-min applications. A single 45-min application facilitates the use of the sealed technique. This occurs once that the tray removal, followed by a change in the bleaching agents and a change in the placement of the tray is not necessary. Furthermore, a previous study showed that a single 45-min application results in a significant whitening effect (16). Moreover, different products that use this technique have been launched in the market (20). However, higher intensity of the tooth sensitivity during the bleaching procedure was observed for a single 45-min application of agent bleaching compared with three 15min applications (16). One possible explanation is that the $\mathrm{pH}$ reduction of the bleaching agent, with time, increased the porosities of enamel, favoring the HP penetration. Also, covering the bleaching agent with a tray during the sealed technique may prevent dehydration of the gel and rapid degradation of active agents in the gel, reducing the HP penetration into the pulp chamber (14). Kown et al. (14) demonstrated in vitro only a minor alteration of HP concentration on the pulp chamber form a baseline to 40 min, when the sealed technique was used. It is important to also emphasize that the application of the bleaching agent increases the porosity of the highly-mineralized enamel, owing to the disruption of the matrix protein (21). Thus, a simple air jet over the bleached more porous enamel can induce the TS. The sealing of the tooth surface by using the bleaching tray reduces the draught stimulus and can contribute to an additional reduction of the TS level.

The bleaching procedure in the present study was performed in only one session because the bleaching efficacy is not the primary outcome. However, the results of this preliminary study indicated that both techniques demonstrated similar and significant tooth color enhancement, as compared with the baseline. Studies that employed a higher concentration of hydrogen peroxide and reported their results in $\Delta \mathrm{E}$ have usually observed an overall color change of 4.7 to 8.7 after one bleaching session (22-24), which is very similar to the results of the present study.

Despite the absence of a statistically significant difference on TS between the two techniques, a clear tendency of TS reduction was observed, when a sealed technique was used. Only three patients presented some TS during the first $20 \mathrm{~min}$ when the sealed technique was used, while seven presented TS for the conventional technique during this same period. The outcomes are preliminary and it is expected that increasing the sample size results in a significant difference on TS. For instance, the sealed bleaching technique has some disadvantages, 
as the necessity of fabrication of a customized bleaching tray (similar to the one used for at-home bleaching). This is more time-consuming and makes the technique more difficult to implement. However, there is a clear tendency to associate in-office with at-home bleaching because this involves a fast and stable bleaching process with lower TS $(19,25)$. Thus, the clinician can use the same bleaching tray for the sealed in-office bleaching and after patient use at-home. Therefore, further investigations of in vivo and in vitro must be performed to focus on the long-term outcomes of tooth sensitivity and color change, using different bleaching agent concentrations in bleaching treatments to confirm this hypothesis.

\section{Resumo}

Apesar da alta taxa de sucesso, os pacientes comumente relatam a ocorrência de sensibilidade dental durante os procedimentos clareadores em consultório. Recentemente, foi demostrado que o uso de uma moldeira customizada (denominada de técnica de consultório selada) reduz a penetração de peróxido. 0 objetivo deste ensaio clínico randomizado foi avaliar sensibilidade dentária e eficiência de clareamento do clareamento selado, em comparação com a técnica convencional de consultório. Vinte pacientes foram aleatoriamente divididos em dois grupos. Em ambos os grupos, um gel de peróxido de hidrogênio a 35\% foi usado em uma simples aplicação de 45 minutos. Para a técnica selada, uma moldeira de clareamento customizada foi confeccionada e cuidadosamente posicionada sobre o agente clareador durante a sessão. A cor foi registrada no início, 7 e 28 dias após a sessão de clareamento usando a espectrofotômetro Vita easy shade. Sensibilidade dental foi registrada durante (20 e 40 minutos) e imediatamente após o tratamento usando uma escala visual analógica. A eficácia do clareamento foi avaliada por ANOVA de medidas repetidas, enquanto o risco absoluto de sensibilidade dental e a sua intensidade foram avaliados pelos testes de Fisher e Mann-Whitney, respectivamente $(\alpha=0.05)$. Nenhuma diferença na eficácia do clareamento foi observada entre as técnicas convencional (7.4 e $8.1 \Delta \mathrm{E}$ ) e selada (7.8 e $8.3 \Delta \mathrm{E}$ ) para ambos os tempos de avaliação. Nenhuma diferença foi observada em relação ao risco de sensibilidade dental $(p=0,15)$. A técnica selada mostrou uma significante diminuição da intensidade de sensibilidade após 40 minutos $(p=0,03)$. A técnica selada de clareamento reduziu a intensidade da sensibilidade durante 0 procedimento clareador, sem afetar a eficácia do clareamento.

\section{References}

1. Bruzell EM, Pallesen U, Thoresen NR, Wallman C, Dahl JE. Side effects of external bleaching tooth bleaching: a multi-centre practice-based prospective study. Br Dent J 2013;215:E17.

2. Martin J, Fernandez E, Bahamondes V, Werner A, Elphick K, Oliveira OB Jr, et al.. Dentin hypersensitivity after teeth bleaching with in-office systems. Randomized clinical trial. Am J Dent 2013;26:10-14.

3. Tay LY, Kose C, Herrera DR, Loguercio AD. Long-term efficacy of inoffice and at-home bleaching: a 2-year double-blind randomized clinical trial. Am J Dent 2012;25:199-204.

4. Farmer DS, Burcham P, Marin PD. The ability of thiourea to scavenge hydrogen peroxide and hydroxyl radicals during the intra-coronal bleaching of bloodstained root-filled teeth. Aust Dent J 2006;51:146152.

5. Kina JF, Huck C, Riehl H, Martinez TC, Sacono NT, Ribeiro AP, et al.. Response of human pulps after professionally applied vital tooth bleaching. Int Endod J 2010;43:572-580.
6. Costa CA, Riehl H, Kina JF, Sacono NT, Hebling J. Human pulp responses to in-office tooth bleaching. Oral Surg Oral Med Oral Pathol Oral Radiol Endod 2010;109:e59-e64.

7. Buchalla W, Attin T. External bleaching therapy with activation by heat, light or laser - a systematic review. Dent Mater 2007;23:586-596.

8. Leonard RH Jr, Smith LR, Garland GE, Caplan DJ. Desensitizing agent efficacy during whitening in an at-risk population. J Esthet Rest Dent 2004;16:49-55.

9. Kose $C$, Reis A, Baratieri LN, Loguercio AD. Clinical effects of at-home bleaching along with desensitizing agent application. Am J Dent 2011;24:379-382.

10. Bonafé $E$, Loguercio $A D$, Reis $A$, Kossatz $S$. Effectiveness of a desensitizing agent before in office tooth bleaching in restored teeth. Clin Oral Invest 2014;18:839-845.

11. Paula E, Kossatz S, Fernandes D, Loguercio A, Reis A The effect of perioperative lbuprofen use on tooth sensitivity caused by in-office bleaching. Oper Dent. 2013;38:601-608.

12. de Paula EA, Loguercio AD, Fernandes D, Kossatz $S$, Reis A. Perioperative use of an anti-inflammatory drug on tooth sensitivity caused by inoffice bleaching: a randomized, triple-blind clinical trial. Clin Oral Invest 2013;17:2091-2097.

13. de Paula E, Kossatz S, Fernandes D, Loguercio A, Reis A. Administration of ascorbic acid to prevent bleaching-induced tooth sensitivity: $A$ randomized triple-blind clinical trial. Oper Dent 2014;39:128-135.

14. Kwon SR, Wertz PW, Dawson DV, Cobb DS, Denehy G. The relationship of hydrogen peroxide exposure protocol to bleaching efficacy. Oper Dent 2013; 38:177-185.

15. Schulz KF, Altman DG, Moher D; CONSORT Group. CONSORT 2010 statement: updated guidelines for reporting parallel group randomized trials. Ann Intern Med. 20101;152:726-732.

16. Reis A, Tay LY, Herrera DR, Kossatz S, Loguercio AD. Clinical effects of prolonged application time of an in-office bleaching gel. Oper Dent 2011;36:590-596.

17. Markowitz K. Pretty painful: why does tooth bleaching hurt? Med Hypotheses 2010;4:835-840

18. Lee DH, Lim BS, Lee YK, Yang HC. Effects of hydrogen peroxide $\left(\mathrm{H}_{2} \mathrm{O}_{2}\right)$ on alkaline phosphatase activity and matrix mineralization of odontoblast and osteoblast cell lines. Cell Biol Toxicol 2006;22:39-46.

19. Sulieman $M$, Addy $M$, MacDonald $E$, Rees JS. The effect of hydrogen peroxide concentration on the outcome of tooth whitening: an in vitro study. Dent Mater 2004; 32:295-299.

20. Spalding M, Taveira LA, de Assis GF. Scanning electron microscopy study of dental enamel surface exposed to 35\% hydrogen peroxide: alone, with saliva, and with 10\% carbamide peroxide. J Esthet Rest Dent 2003;15:154-164.

21. Yang Z, Zou M, Lin X, Yang $X$, Li N, Wang K. Novel method to measure enamel surface porosity with hydrogen peroxide bleaching. Am J Dent 2009;22:283-289.

22. Marson FC, Sensi LG, Vieira LC, Araújo E. Clinical evaluation of inoffice dental bleaching treatments with and without the use of lightactivation sources. Oper Dent 2008;33:15-22.

23. Da Costa J, Lubisich E, Ferracane J, Hilton T. Comparison of efficacy of an in-office whitening system used with and without a whitening priming agent. J Esthet Rest Dent 2011;23:97-104.

24. Deliperi S, Bardwell DN, Papathanasiou A. Clinical evaluation of a combined in-office and take-home bleaching system. J Am Dent Assoc 2004;135:628-634.

25. Matis BA, Cochran MA, Wang G, Eckert GJ. A clinical evaluation of two in-office bleaching regimens with and without tray bleaching. Oper Dent 2009;34:142-149. 